\title{
Comparison of final visual acuity: cataract surgery with intraoperative complications versus non intraoperative complications
}

\author{
Comparação de acuidade visual final: cirurgias de catarata \\ com intercorrências versus sem intercorrências
}

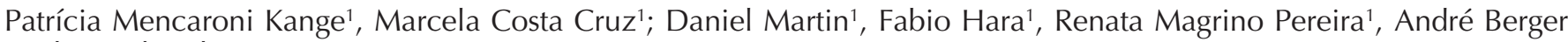
Emiliano da Silva ${ }^{2}$

\begin{abstract}
Objective: Compare visual acuity (VA) of patients after cataract surgery with and without intraoperative complications regarding possible factors that contributed to the outcome on postoperative follow-up. Methods: Longitudinal, retrospective study that evaluated 179 medical records of patients who underwent cataract surgery under the technique Phacoemulsification (PHACO) in the Suel Abujamra Institute from february to july 2013. Patients were divided into two groups concerning presence or absence of intraoperative complications. Data were analyzed using t-test methods for two samples or (ANOVA) Analysis of Variance. Exclusion criteria were: patients with previous ocular surgery, retinopathy related to diabetes, either proliferative or severe non proliferative, other retinopathies, optic disc cup equal to or greater than $0,7 \times 0,7$, use of more than two ocular hypotensive medications, only one eye, cataract due to uveitis, trauma or congenital. Results: 37 (20.7\%) patients had intraoperative complications and 142 (79.3\%) had not. Average age of patients was 70.33 years. There were $49.7 \%$ surgeries of the right eye and $50.3 \%$ of the left eye. There were $29.05 \%$ diabetic patients, of which $29.73 \%$ had intraoperative complications and $28.87 \%$ had not. From the 179 patients, $77.65 \%$ reached a final VA of $20 / 40$ or better, considering that patients with intraoperative complications reached a VA of about $59.46 \%$ and patients without intraoperative complications of about $82.40 \%$. The main complication was posterior capsular tear. Conclusion: After entire evaluation, we realized that factors that influenced lower final VA, with statistical significance, were intraoperative complications and patient age.
\end{abstract}

Keywords: Crystalline; Cataract; Cataract extraction; Eye surgical procedures; Phacoemulsification; Visual acuity

\section{RESUMO}

Objetivo: Comparar a acuidade visual (AV) final dos pacientes submetidos à cirurgia de catarata com e sem complicações intraoperatórias e possiveis fatores que contribuíram para o resultado ao final do pós-operatório. Métodos: Análise dos prontuários de 179 pacientes, retrospectivo, longitudinal, operados de fevereiro a julho de 2013 no Instituto Dr. Suel Abujamra, pela técnica de facoemulsificação (FACO), divididos em dois grupos: com e sem complicações intraoperatórias. Os dados obtidos foram analisados pelos métodos teste-t para duas amostras ou Análise de Variância (ANOVA). Os critérios de exclusão foram pacientes com cirurgia ocular prévia, retinopatia diabética proliferativa ou não proliferativa grave, outras retinopatias, escavação do disco óptico igual ou maior que 0,7x0,7 ou uso de mais de dois hipotensores oculares, olho único, catarata secundária à uveíte, traumática ou congênita. Resultados: Dos 179 pacientes, 37 (20,7\%) tiveram complicações intraoperatórias e $142(79,3 \%)$ não tiveram complicações intraoperatórias. A média da idade dos pacientes foi de 70,33 anos. $O$ olho direito foi o operado em 49,7\% dos casos, e o olho esquerdo em 50,3\%. O diabetes mellitus estava presente em $29,05 \%$ dos casos, sendo $29,73 \%$ de pacientes com complicação e $28,87 \%$ sem complicações. Do total, $77,65 \%$ atingiram uma AV final $20 / 40$ ou melhor, sendo que nos pacientes com complicação a média para esta AV foi de 59,46\% e no grupo sem complicações foi de $82,40 \%$. A principal complicação foi ruptura de cápsula posterior. Conclusão: Após toda a análise, verificamos que os fatores que implicaram com significância estatística em menor AV final foram as complicações intraoperatórias e a idade dos pacientes.

Descritores: Cristalino; Catarata; Extração de catarata; Procedimentos cirúrgicos oftalmológicos; Facoemulsificação; Acuidade visual

\footnotetext{
1 Residency Program in Ophthalmology, Institute Service Suel Abujamra, São Paulo, SP, Brazil.

${ }^{2}$ Cataract Surgery Section, Medical Residency Program in Ophthalmology University of Santo Amaro, São Paulo, SP, Brazil.
}

The authors declare no conflicts of interest

Received for publication 14/10/2014 - Acceptrd for publication em 05/01/2015 


\section{INTRODUCTION}

C ataracts are the leading cause of reversible blindness in the developing countries. WHO estimated in 2010 that there are almost 18 million people bilaterally blind from cataract in the world, representing almost half of the causes of blindness due to eye diseases. The blindness ratio due to cataract in relation to all other eye diseases ranges from 5\% in Western Europe, North America and in the more developed countries in the Western Pacific region, to $50 \%$ or more in poorer regions ${ }^{(1)}$ It may be from senile, congenital, traumatic or secondary etiology.

The gradual increase of life expectancy in our country caused a subsequent increase in the prevalence of this disease in the last decades. ${ }^{(1)}$ Despite popular belief, the majority of the population believes that cataract surgery is a definitive treatment to restore the vision ${ }^{(2,3)}$, thus allowing an improvement in the quality of life and reintegration into the labor market ${ }^{(4)}$.

Cataract extraction is the most commonly performed surgery in the USA, with 1.7 million surgeries perfomed annually, and phacoemulsification (FACO) is the chosen technique ${ }^{(5)}$. Studies carried out worldwide in the past 20 years have shown that the phacoemulsification is a safe and effective procedure to treat patients with mild to advanced cataracts ${ }^{(6,7)}$.

A complication feared during the cataract surgery is the loss of barrier between the anterior segment and the vitreous, which may be due to the posterior capsule rupture (PCR) or zonular detachment ${ }^{(8)}$. However, other intraoperative complications can be added, such as vitreous prolapse, vitreous loss and core in the vitreous, which remain significant adverse events in the cataract surgery ${ }^{(9)}$, decreasing the likelihood of achieving good postoperative final visual acuity ${ }^{(8,9)}$.

Posterior capsule rupture is the most common intraoperative complication during the ophthalmologist learning phase ${ }^{(9)}$, despite being potentially serious in the cataract surgery, and may be associated to vitreous loss, poor visual acuity, retinal detachment, endophthalmitis, among others ${ }^{(7,9)}$. In the literature limited to studies with over 1,000 surgeries, they show a PCR rate of $1.9 \%$ to $5.2 \%$ and vitreous loss between $1.1 \%$ and $5.0 \%{ }^{(8)}$. Other risk factors for intraoperative complications described in other studies include advanced age ${ }^{(9)}$ and previous ocular pathology ${ }^{(7,10)}$.

Thus, the present study aimed to compare the final visual acuity of patients undergoing cataract surgery by the phacoemulsification technique separating them into two groups: those with and without intraoperative complications, assessing possible factors that influence the final visual acuity at the end of the postoperative period.

\section{Methods}

A study was conducted in the Medical Residency Service in Ophthalmology at Institute Suel Abujamra, retrospective, longitudinal, by the analysis of medical records of 179 patients undergoing cataract surgery by the second and third year residents between the months of February and July 2013 by means of the phacoemulsification technique. The patients were divided into 2 groups, the first group of patients with intraoperative complications and the second one without intraoperative complications. The primary assessment was the development of visual acuity, and the presence or absence of intraoperative complications. Other variables analyzed were age, the presence of diabetes mellitus, the year of medical residency and the type of apparatus used for the procedure (Legacy®- Surgical Series 20000 Legacy-STTL; Alcon Laboratories, California - USA, Universal®- Alcon Universal II; Alcon Laboratories, California - USA and Vizual ${ }^{\circledR}$ - Vizual - American Optisurgical Inc; Lake Forest, California - USA). It should be noted that the resident was supervised by an experienced surgeon (preceptor), present in the operating room and always available for any king of complications. In case of intraoperative complications, the preceptor would take the surgery over and deal with the complication the best possible way.

As inclusion criteria for the study patients were accepted with cataract and presenting preoperative visual acuity worse than 20/60. As exclusion criteria, the patients excluded from the study were the ones with previous intraocular surgery, severe proliferative or non-proliferative diabetic retinopathy, severe hypertensive retinopathy, other retinopathies, excavation of the optical disc bigger than or equal to $0.7 \times 0.7$ or the use of 2 or more ocular hypotensive, single eye, cataract secondary to uveitis, traumatic or congenital. The patients with postoperative complications such as cases of resuture and corneal edema were also excluded from the study.

The measures of visual acuity were made according to the Snellen scale, with values of 20/20 to 20/400 and including the patient counting fingers $(\mathrm{CF})$, perception of hand motion (HM) and light perception (LP).

We classified the measures on a number scale, and we considered how the development in how many lines in the Snellen scale the individual had changed, for example:

- If before surgery the visual acuity was $20 / 100$ and after surgery was 20/80 there was 1 point in improvement (Evolution $=+1)$.

- If before surgery the visual acuity was $20 / 100$ and after surgery was 20/20 there were 8 points in improvement (Evolution $=+8)$.

- If before surgery the visual acuity was 20/60 and after surgery was 20/200 there were 6 points in worsening $($ Evolution $=-6)$.

The analysis mainly used the $\mathrm{t}$ test for two samples or ANOVA - Analysis of Variance, to compare the means of developments (for these tests we checked the statistical hypotheses for safe use and they were met). The test for two proportions was used to compare the percentages.

\section{Results}

From the 179 patients analyzed in the period, 37 had intraoperative complications (20.7\%) and 142 did not have intraoperative complications (79.3\%), as shown in Graph 1. 
Graph 1

Percentage distribution of patients

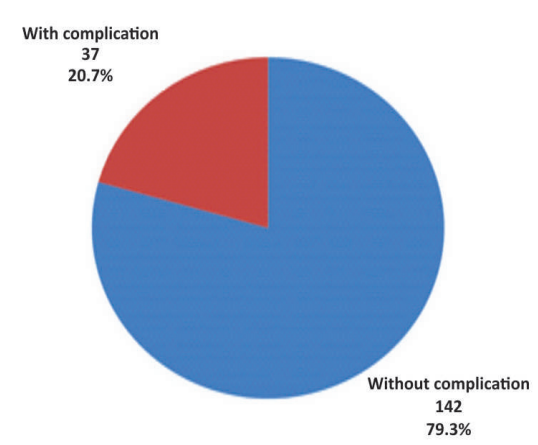

The mean age of the patients was 70.33 years. The right eye was operated in $49.7 \%$ of the cases, and the left eye in $50.3 \%$ of them. Diabetes mellitus was present in $29.05 \%$ of the cases, and $29.73 \%$ of the patients presented some complication and $28.87 \%$ of the patients did not present any complication. From the total of patients, $77.65 \%$ achieved a final visual acuity of $20 / 40$ or better, and the mean for this visual acuity was $59.46 \%$ in patients presenting complication and $82.40 \%$ of the patients in the group with no complication. The main complication was posterior capsule rupture. Patients were followed for an average period of 61 days and 66 days in the group with complications and 57 days in the group without complications.

Table 1 and Graph 2 show the visual acuity of the patients.

Table 1

General distribution of pre and post operative visual acuity

\begin{tabular}{|c|c|c|c|c|c|c|c|c|c|c|c|c|c|c|c|c|c|c|}
\hline \multirow{7}{*}{$\begin{array}{l}\text { Preoperative } \\
\text { visual } \\
\text { acuity }\end{array}$} & \multicolumn{17}{|c|}{ Postoperative visual acuity } & \multirow{7}{*}{ Total } \\
\hline & & & & 2 & 2 & 2 & 2 & 2 & 2 & & & & & & & & & \\
\hline & & & & 0 & 0 & 0 & 0 & 0 & 0 & 2 & 2 & 2 & 2 & 2 & 2 & 2 & 2 & \\
\hline & & & & I & I & I & 1 & l & l & 0 & 0 & 0 & 0 & 0 & 0 & 0 & 0 & \\
\hline & & $\mathrm{P}$ & & 4 & 2 & 1 & 1 & 1 & 1 & I & l & l & l & l & l & l & l & \\
\hline & $\mathrm{P}$ & M & $\mathrm{C}$ & 0 & 0 & 6 & 3 & 2 & 0 & 8 & 6 & 5 & 4 & 3 & 3 & 2 & 2 & \\
\hline & $\mathrm{L}$ & M & $\mathrm{D}$ & 0 & 0 & 0 & 0 & 0 & 0 & 0 & 0 & 0 & 0 & 3 & 0 & 5 & 0 & \\
\hline HP & & & & & & & & & & & & & 1 & & & 1 & & 2 \\
\hline LM & & & & & 1 & & & & 1 & & & & & & 2 & & & 4 \\
\hline $\mathbf{C F}$ & 1 & & & & 1 & & & & 1 & & 1 & & 1 & 4 & 4 & & 3 & 16 \\
\hline $20 / 400$ & & & & & & & & & 2 & 5 & 2 & 3 & & 4 & 5 & 7 & 1 & 29 \\
\hline $20 / 200$ & 1 & & & & 1 & & 1 & & 2 & 1 & 1 & 3 & 4 & 6 & 19 & 11 & 8 & 58 \\
\hline $20 / 160$ & & & & & & & & & & & & & & & 1 & 2 & & 3 \\
\hline $20 / 130$ & & & & & & & & & & & & & & & & 1 & & 1 \\
\hline $20 / 120$ & & & & & & & & & 1 & & & & & & & 2 & 1 & 4 \\
\hline $20 / 100$ & & & & & & & & & 1 & & 5 & 4 & 2 & 6 & 8 & 7 & 7 & 40 \\
\hline $20 / 80$ & & & 1 & & & & & & 1 & & & & 2 & & 6 & 5 & 1 & 16 \\
\hline $20 / 60$ & & & & & & & & & & & & & 1 & 2 & 2 & & 1 & 6 \\
\hline $20 / 50$ & & & & & & & & & & & & & & & & & & 0 \\
\hline $20 / 40$ & & & & & & & & & & & & & & & & & & o \\
\hline $20 / 33$ & & & & & & & & & & & & & & & & & & 0 \\
\hline $20 / 30$ & & & & & & & & & & & & & & & & & & 0 \\
\hline $20 / 25$ & & & & & & & & & & & & & & & & & & o \\
\hline $20 / 20$ & & & & & & & & & & & & & & & & & & 0 \\
\hline Total & 2 & $\mathbf{0}$ & 1 & 0 & 3 & $\mathbf{0}$ & 1 & 0 & 9 & 6 & 9 & 10 & 11 & 22 & 47 & 36 & 22 & 179 \\
\hline
\end{tabular}


Graph 2

General distribution of pre and post operative visual acuity

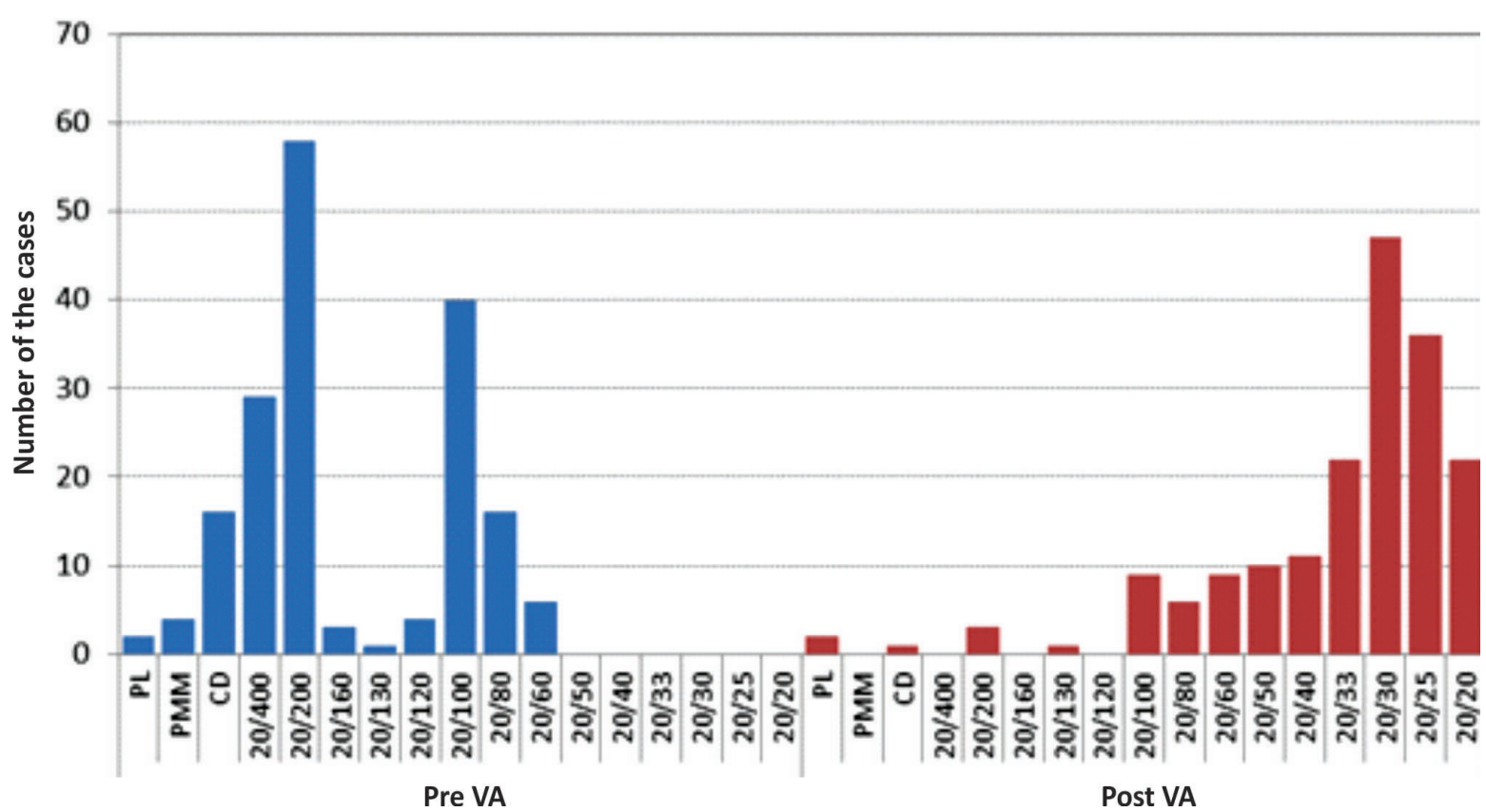

Note that the great majority of patients showed improvement. This is best seen in Graphs 3 and 4 which show the development of each patient and also the general mean development.

\section{Graph 3}

Individual development of patients

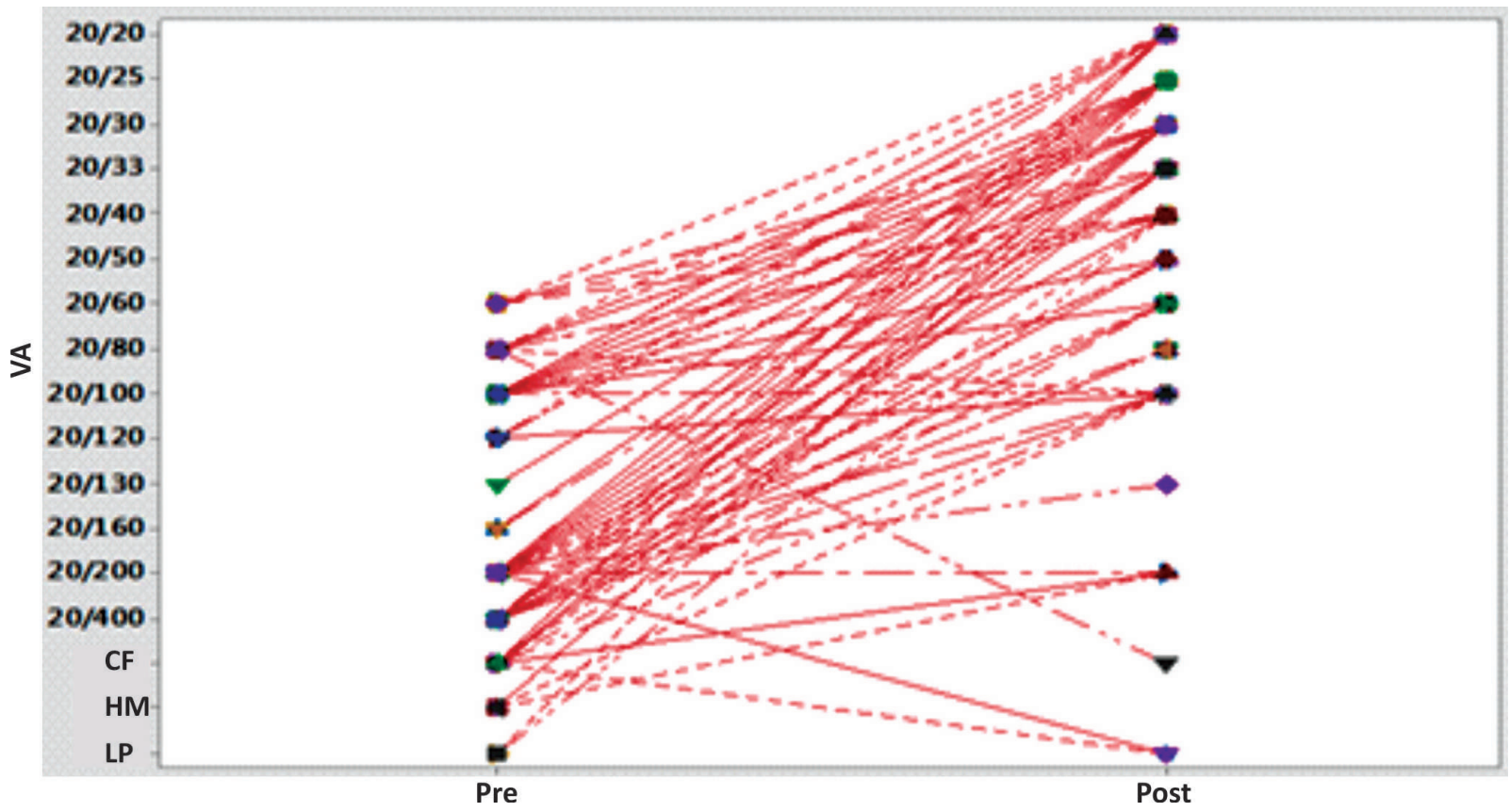




\section{Graph 4}

\section{Mean development of patients}

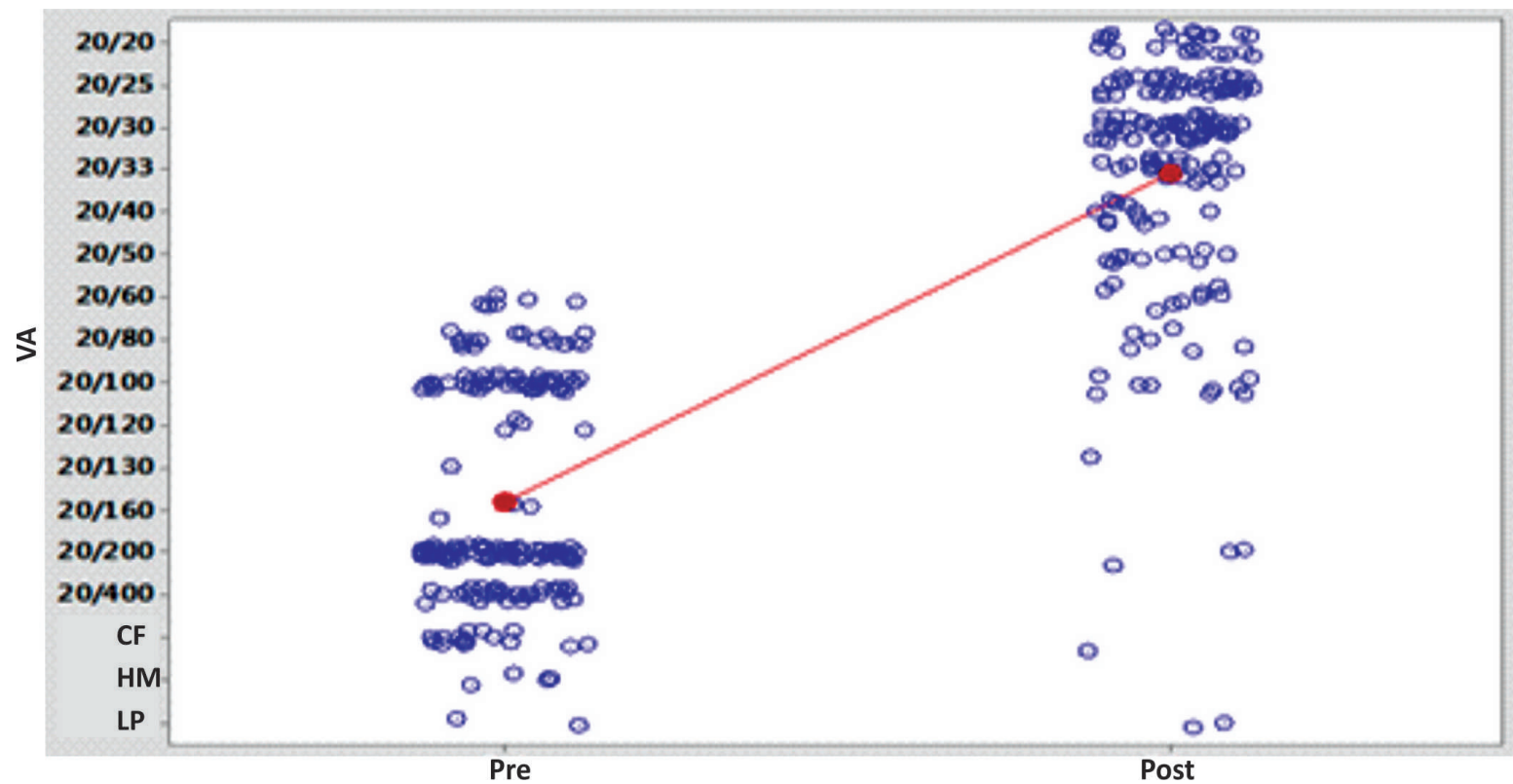

Comparing the visual acuity among patients presenting and not presenting intraoperative complication we realized that the mean developments were different, with a significant difference between the mean development in both groups (Graph 5). In graph 6 we have the distribution of visual acuity development for patients with and without complication. Note that the patients presenting complication have a higher variability of outcomes.

\section{Graph 5}

Mean development of patients - Complication $\mathrm{x}$ no complication

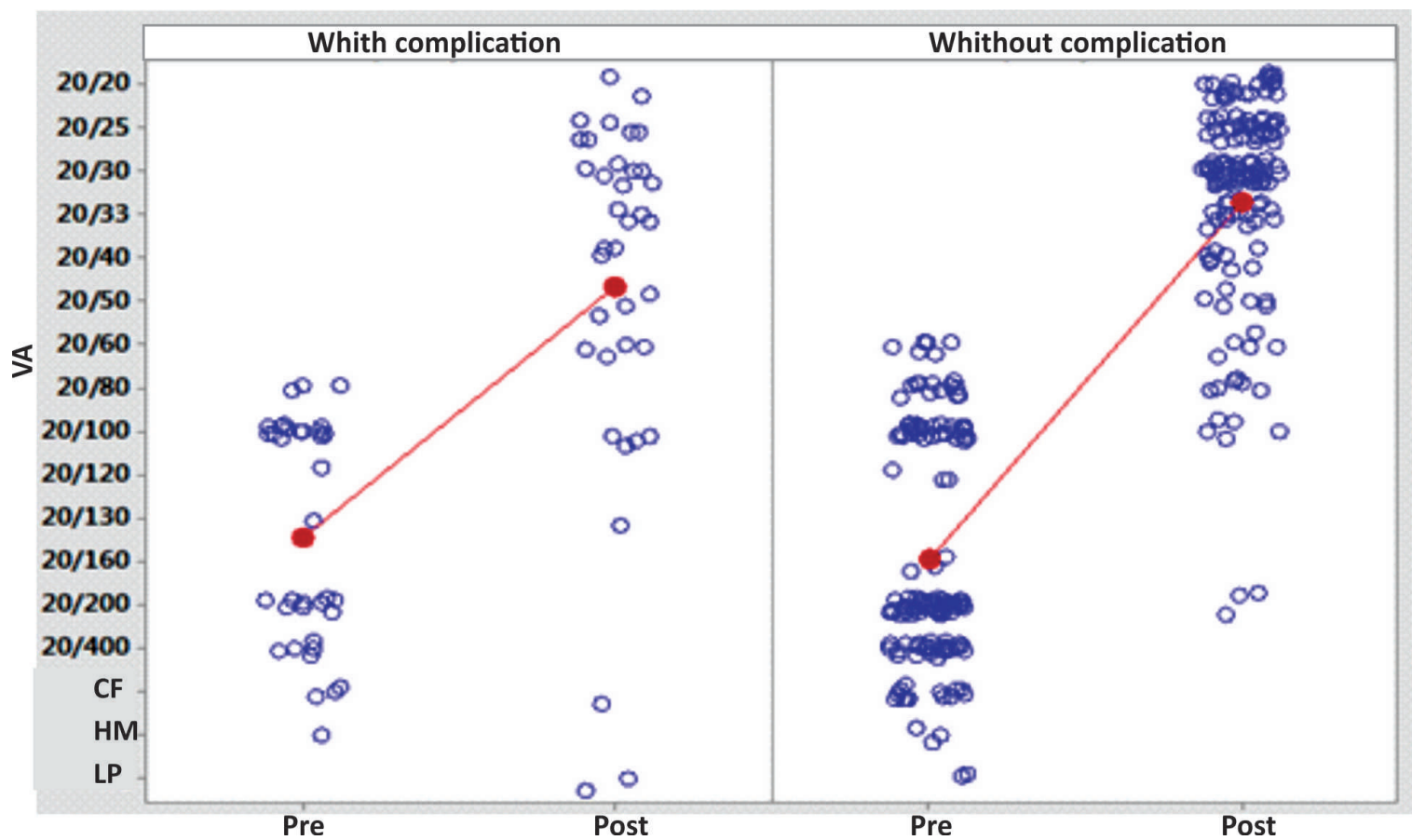


Graph 6

Percentage distribution of development scores - Complication $\mathrm{x}$ no complication

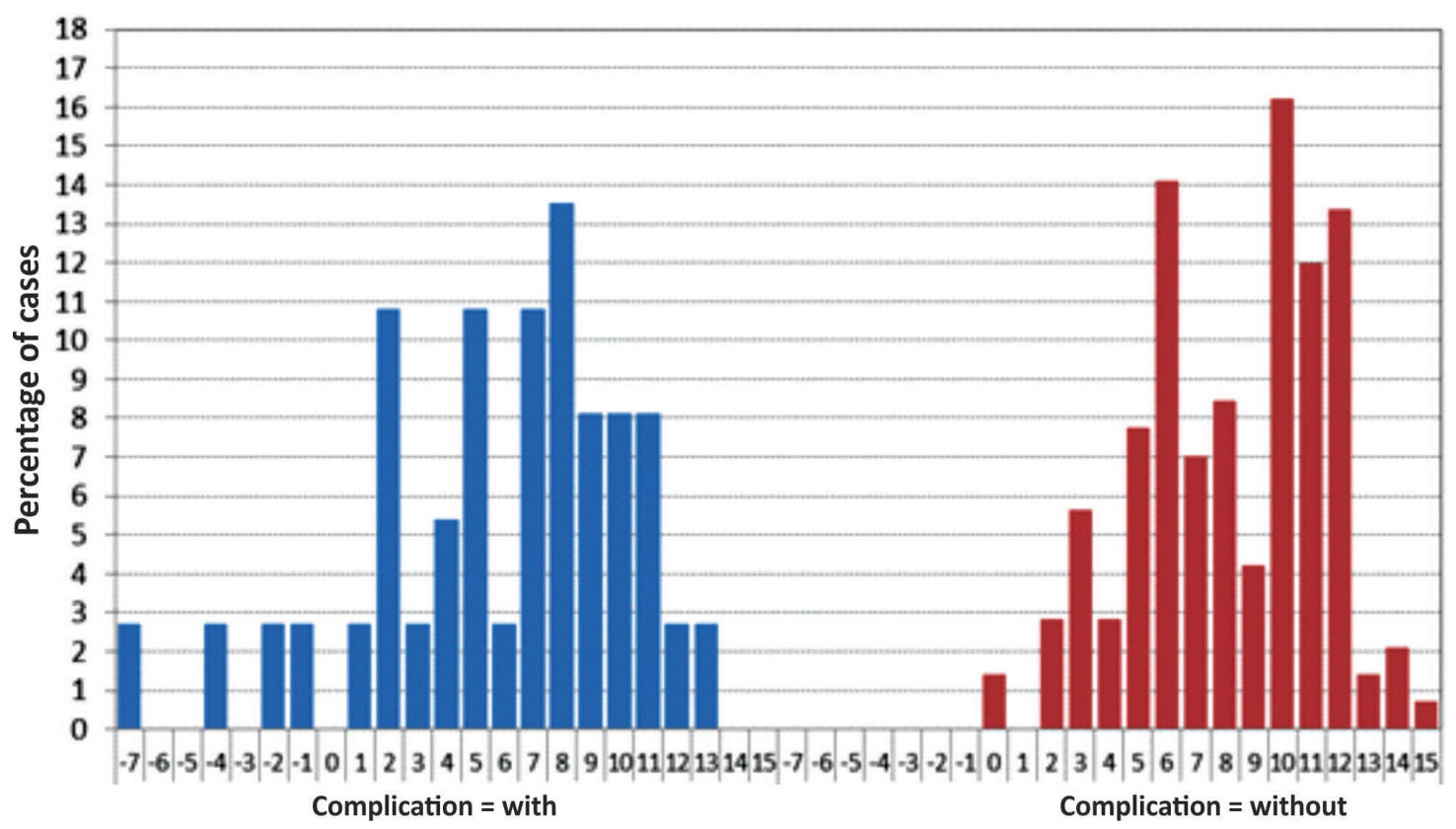

The assessment of patients in the Diabetes Mellitus group shows that the development of visual acuity in patients with diabetes and without diabetes was very similar, with the diabetes group having a slightly higher mean development, but there is no significant difference between mean developments. (Graphs 7 and 8).

Graph 7

Percentage distribution of evolution scores - Diabetes

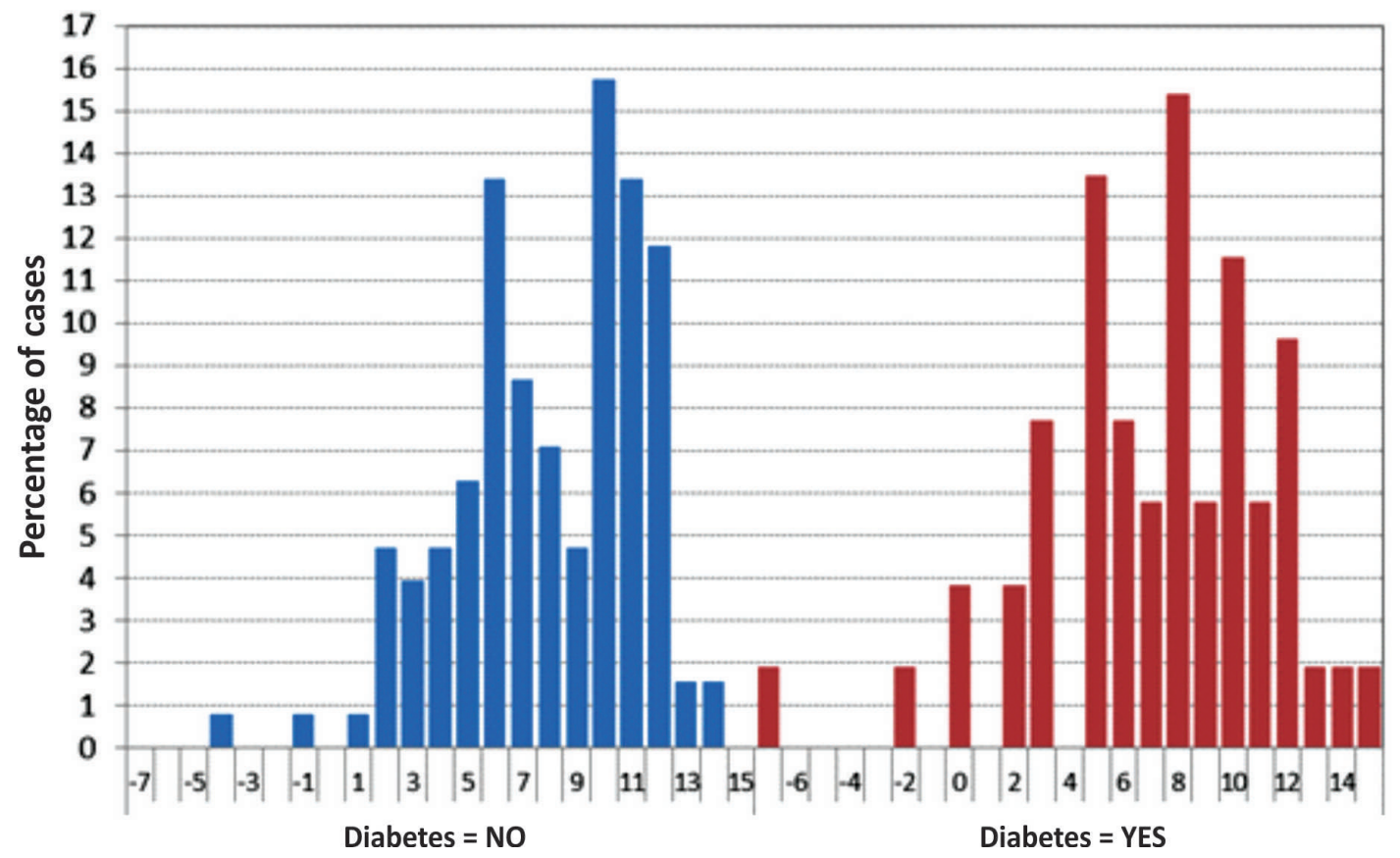




\section{Graph 8}

Mean development of patients - Diabetes

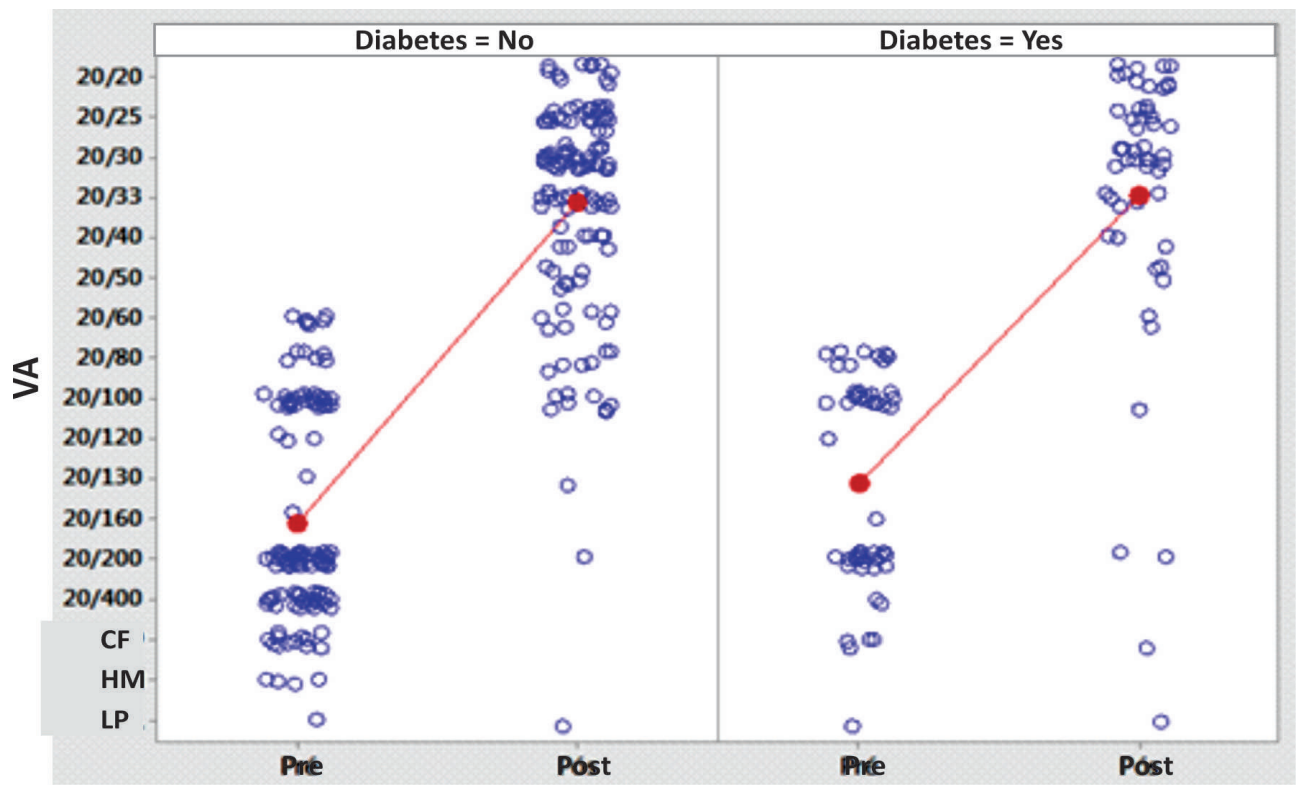

Considering the group of second and third year residents, it is noted that the devlopment of visual acuity in both groups (group R2 and group R3) was very similar, with no significant difference between mean developments (Chart 9).

\section{Graph 9}

Percentage distribution of evolution scores - Resident

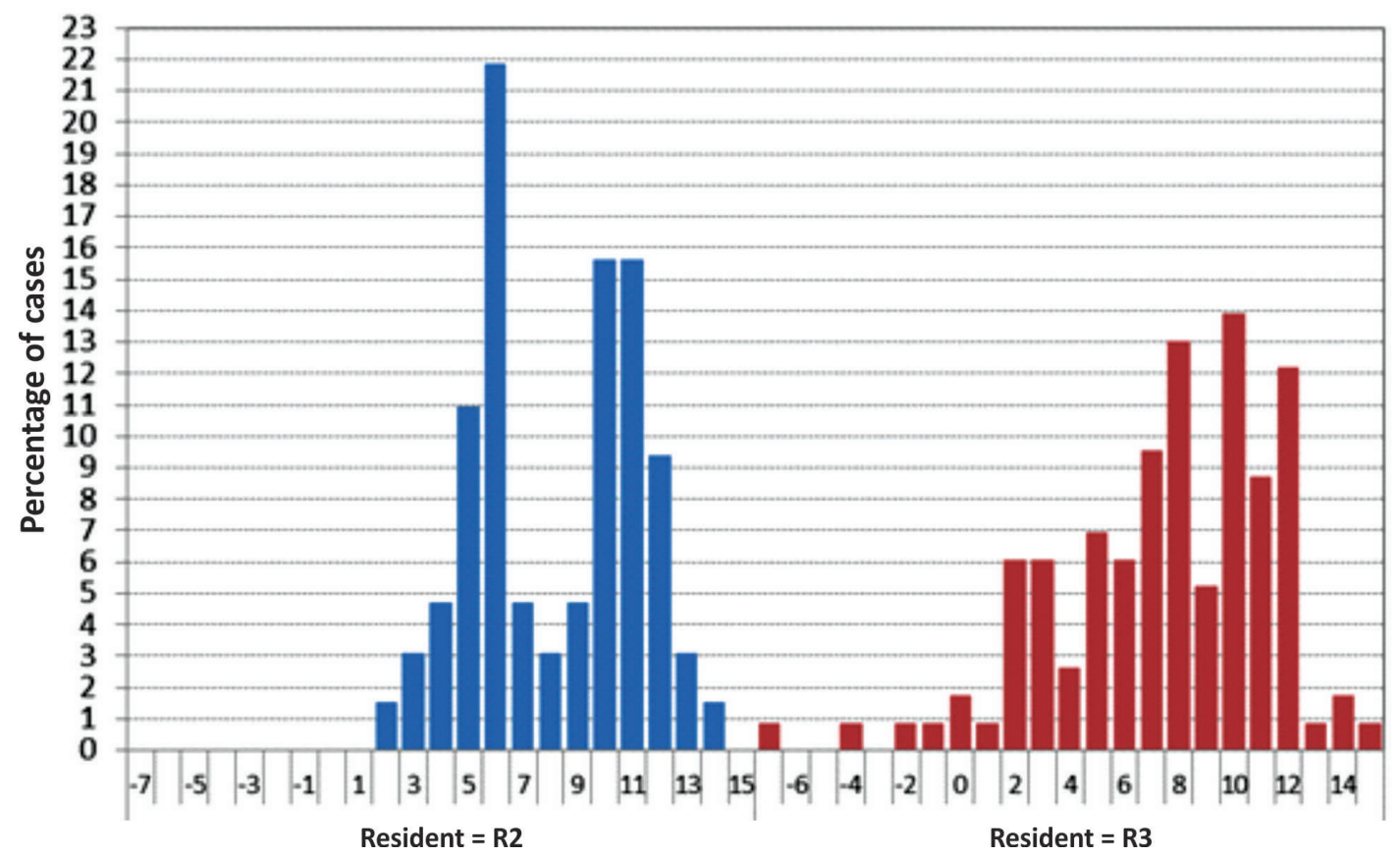

The analysis of visual acuity development separated by the type of apparatus used for the procedure (Legacy®, Universal ${ }^{\circledR}$ and Vizual®) shows that the mean development with the three apparatuss was very similar, with Legacy® showing a slightly higher mean development and no patient worsening the visual acuity. All worsening occurred in Vizual® (Chart 10). The statistical tests let us conclude that there was no significant difference between the variability and the mean development of the groups. 


\section{Graph 10}

Percentage distribution of evolution scores - Apparatus

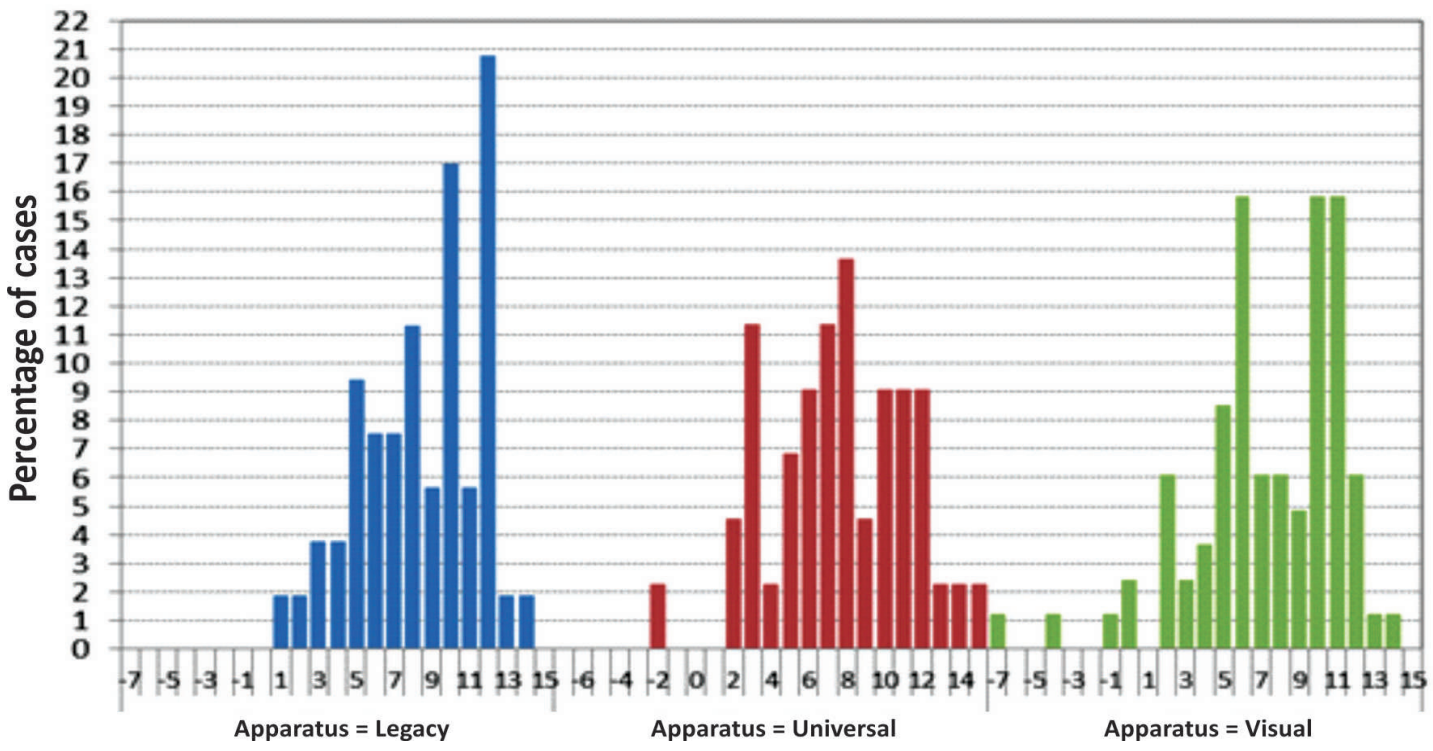

Age is a factor of a continuous variable. The table shows a tendency of decreased visual acuity as the age increases. Graph 11 presents the dispersion between the two measures, and a certain decrease in the development is noticed as the age increases, but there is also a great dispersion in the results.

\section{Graph 11}

Graph of dispersion between age and development of visual acuity

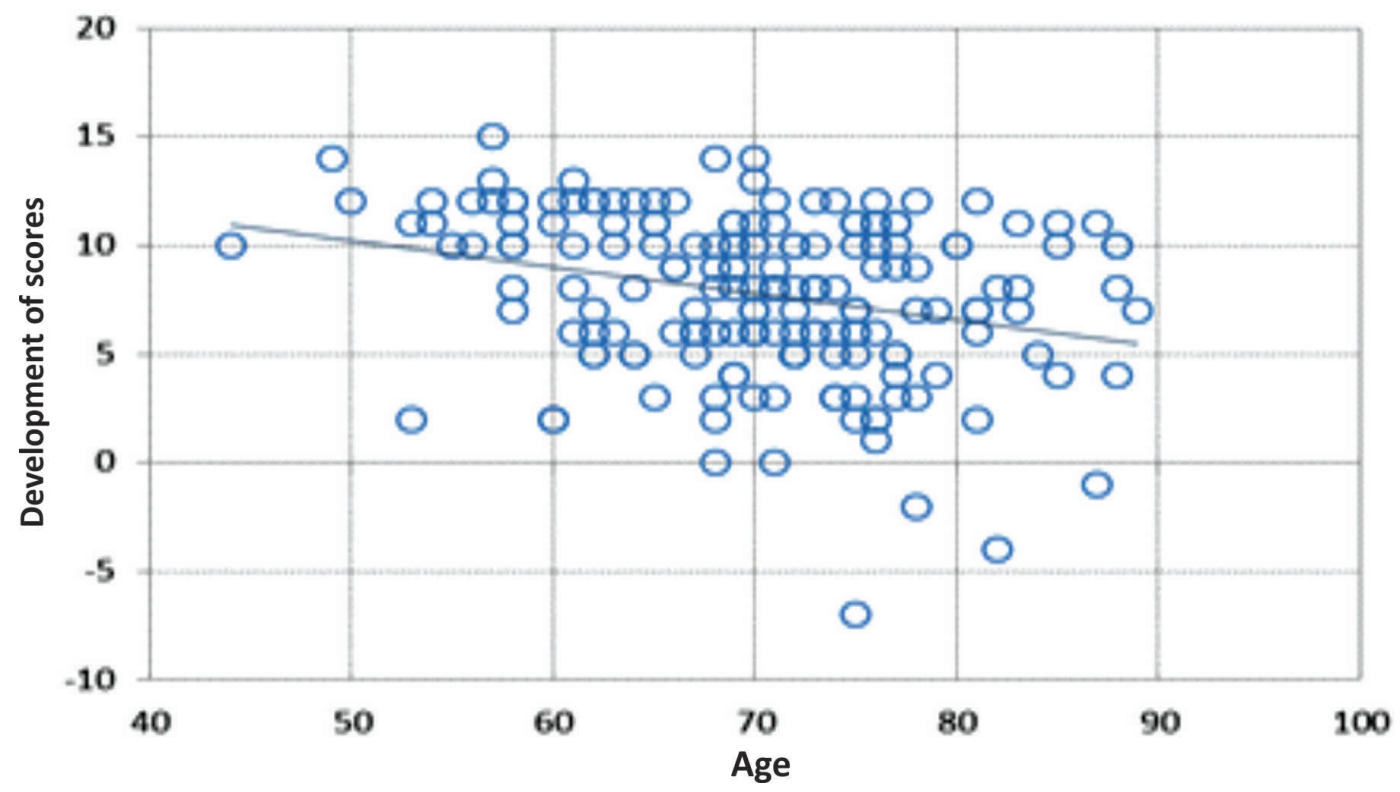

All the results above were presented by indivudual analysis of the factors in comparison with visual acuity.

From now on we present a comparative analysis of the factors and the visual acuity.

Diabetes mellitus as a cause of poor development in the comparison between the groups was low, i.e., the difference in development between having or not diabetes is about the same in both groups of complication. We note that the lines are almost parallel in chart 12 indicating statistical irrelevance. 
Graph 12

Mean development of patients - Diabetes

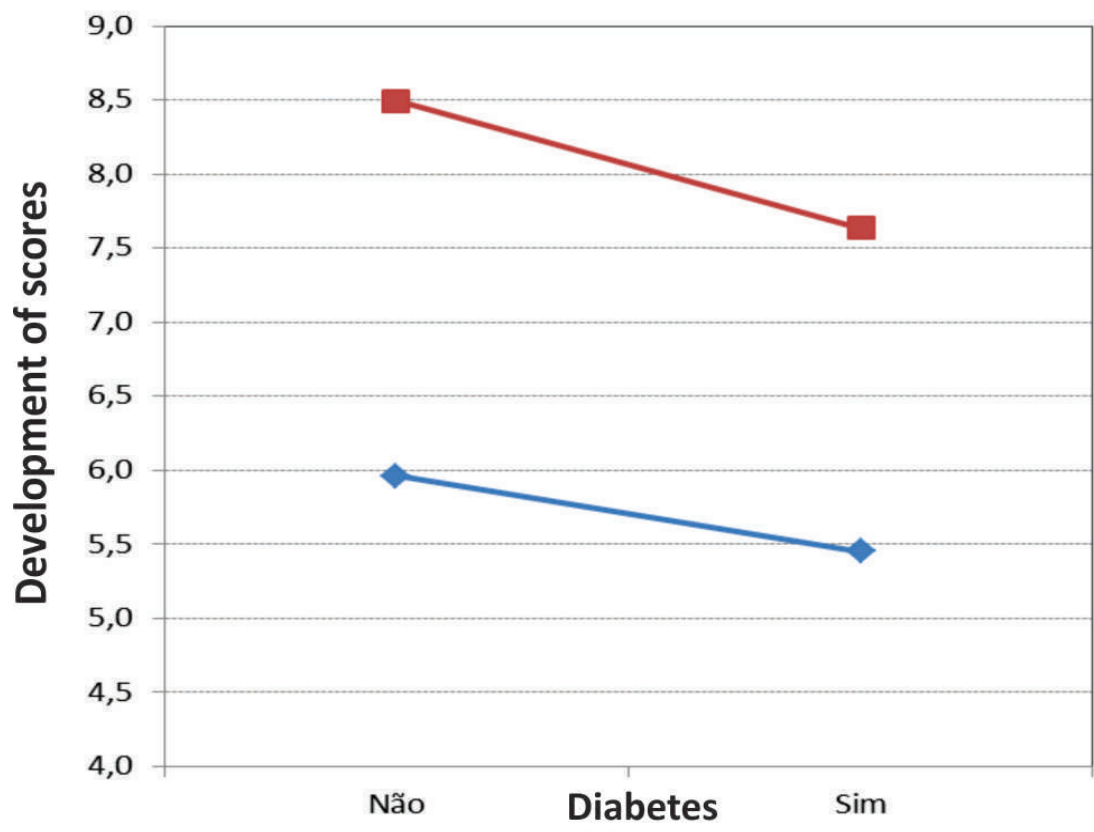

with complication

$\rightarrow$ without complication

When comparing the scores between the years of each resident, the means were similar when there were no complications, but there was a difference when there were complications with the third-year residents (R3), with a lower mean development than the second-year residents ( R2) (Chart 13).

\section{Graph 13}

Mean development of patients - Resident

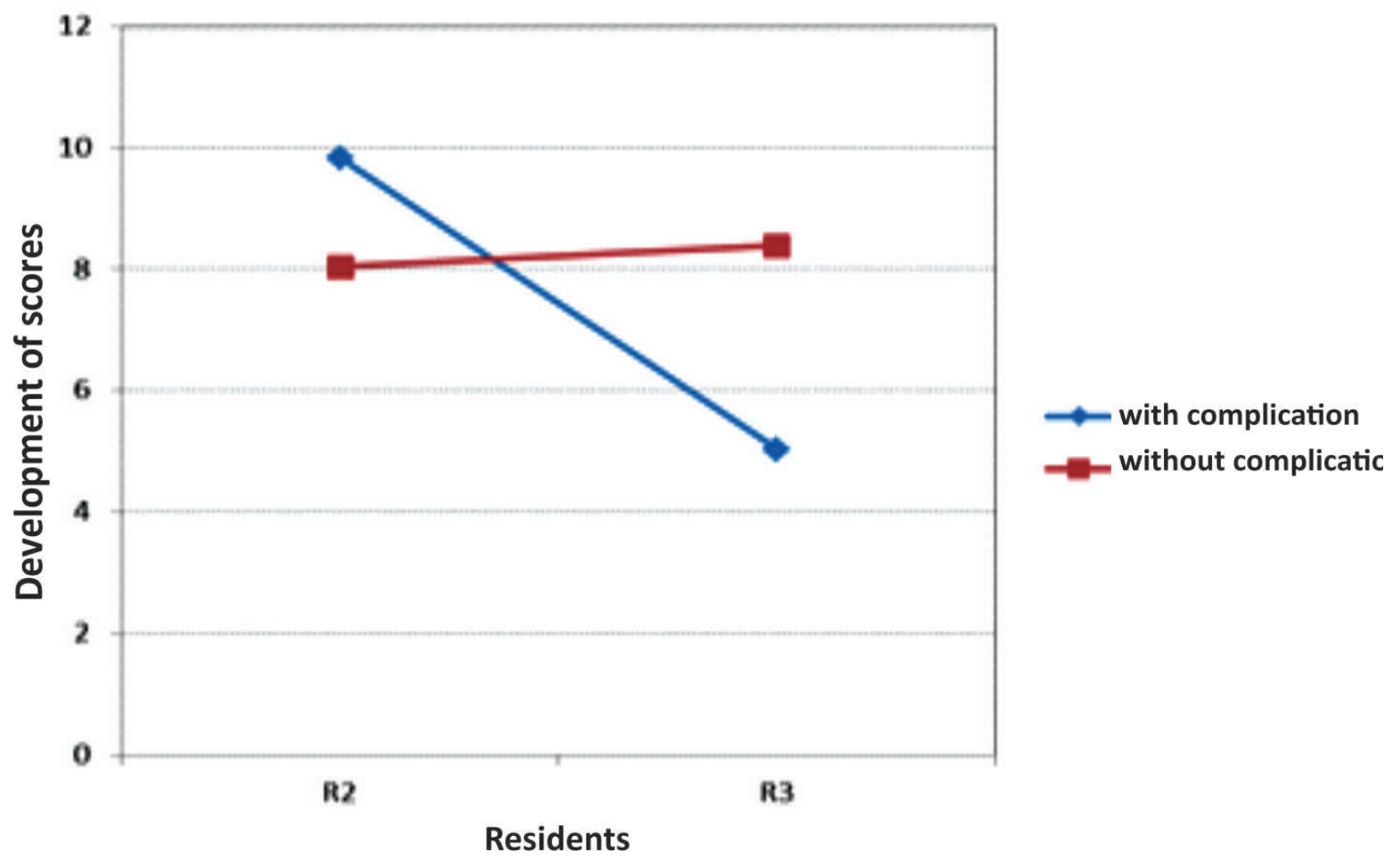


Regarding the interaction between the groups and the apparatus used, we noted that the group of the apparatus Legacy ${ }^{\circledR}$ presented complication and alowe mean development than the others. The most important information for our analysis is the descriptive level of the interaction Complication x Apparatus ${ }^{\circledR}$, which was 0.397 indicating no significant interaction, i.e., the difference between visual acuity developments in the three apparatus can be considered the same in both groups (Table 2).

Table 2

ANOVA for the develoment of complication and apparatus scores

\begin{tabular}{l|ccccc}
\hline \multicolumn{1}{c|}{ Source } & Degree of freedon & Sum of squares & Mean squares & F-statistics & Descriptive level \\
\hline Complication & 1 & 102.89 & 102.89 & 8.18 & 0.005 \\
Apparatus & 2 & 33.41 & 16.70 & 1.33 & 0.268 \\
Complication $x$ & 2 & 23.40 & 11.70 & 0.93 & 0.397 \\
Apparatus & 173 & 2.176 .64 & 12.58 & & \\
Residue & $\mathbf{1 7 8}$ & $\mathbf{2 . 4 0 2 . 1 8}$ & & & \\
\hline Total & &
\end{tabular}

Regarding the factor age, in order to check if the relationship between the groups was different we made a Regression Analysis, and we obtained the results shown in table 3 in which we conclude that the Complication does not significantly affect the relationship between Development and Age ( $\mathrm{p}$-value $=0.058$ for the interaction Age $\mathrm{x}$ Complication).

Table 3

ANOVA for regression between the development of the scores and age considering the complications

\begin{tabular}{lcccrr}
\hline Source & Degree of freedon & Sum of squares & Mean squares & F-statistics & Descriptive level \\
\hline & 1 & 128.97 & 128.97 & 11.10 & 0.001 \\
Age & 1 & 25.94 & 25.94 & 4.23 & 3.63 \\
Complication & 1 & 42.21 & 11.62 & & 0.058 \\
Age x Complication & 175 & 2.033 .66 & & \\
Residue & $\mathbf{1 7 8}$ & $\mathbf{2 . 4 0 2 . 1 8}$ & & \\
\hline Total & & & & \\
\hline
\end{tabular}

\section{Discussion}

The intraoperative complication rate in the present study was $20.7 \%$, with the great majority being due to the posterior capsule rupture. Compared to the published works in which the posterior capsule rupture rates were found around 1.9 to $5.2 \%{ }^{(8)}$, we can considere the complication rate as high, even compared to the procedure studies performed only by resident doctors ${ }^{(6,11)}$. However, the vast majority of patients showed improvement of visual acuity, regardless of complications. When the variables are analyzed separately, the factors involved with the statistical significance in a worse final visual acuity were the intraoperative complications and the patient age; no other variable was studied with statistical significance. The facts of patients having diabetes mellitus, the device used for the procedure and the year of residency in ophthalmology alone were not statistically significant.

This finding is consistent with most works in the art, which show that the intraoperative complications were more related to a worse final visual acuity ${ }^{(8,9)}$. Age has also been shown in other studies to be a risk factor associated with a poorer final visual acuity, because the vision of the elderly usually declines with age, especially after 70 years old, even without pathological findings ${ }^{(12)}$.
In the comparisons between groups with and without complications, besides the fact already presented that the group with complications presented worse final visual acuity than the group without complication, we realized that the factor wich influenced the group with complication is the resident surgeon. Although it has no statistical significance alone, as already found in other studies ${ }^{(9,11)}$, in the comparison of final visual acuity in the group with complications R3 had a worse development than $\mathrm{R} 2$. This result is possibly due to the fact that in our service generally R3 performs the surgery alone, only being taught during complications, but trying to solve them, while $\mathrm{R} 2$ is in the learning phase and always followed by the preceptor. Another possible explanation is based on the current phacoemulsification teaching method, which requires a specific theoretical charge for the use of the phacoemulsification in order to improve the performance and reliability of the surgical technique. Probably the secondyear residents have more conditions to study the theoretical part than the third-year residents, whise focus is to effectively perform surgeries ${ }^{(13)}$. The resident's learning curve for the phacoemulsification technique has been described to decrease the vitreous loss rates, with the gain of surgeon expertise ${ }^{(9)}$, and thus the resident who will start learning phacoemulsification shall have an experienced preceptor by his side to minimize the risk of complications ${ }^{(6)}$. 
The other variables were not statistically significant in the comparison between the two groups.

Although no statistically significant, the fact of having a greater number of complications with the apparatus Vizual® is probably due to the service has 2 units of this apparatus, therefore performing a higher total number of surgeries in them.

\section{Conclusion}

Despite the high complication rate found in the current study, the great majority of patients had a better final visual acuity than the preoperative one. However, intraoperative complications and the advanced age of the patients accounted for a lower final visual acuity than expected with the cataract surgery. In patients with intraoperative complications, the experience of the resident doctor was a significant factor for a worse result than expected. Thus, it is unquestionable that the learning curve by the resident in the current chosen technique phacoemulsification - is the main obstacle to be overcome in order to avoid low visual acuity in the patients operated, as well as the detection and intervention of possible risk factors during the preoperative procedure.

\section{References}

1 Carlos Eduardo Leite Arieta, Marco Antônio Rey de Faria. Série Oftalmologia Brasileira - Cristalino e Catarata. $3^{\circ}$ ed. Rio de Janeiro: Cultura Médica; 2013 - 2014.

2 Edméa Rita Temporini, Newton Kara Júnior, Newton Kara José, Nilo Holzchuh. Popular beliefs regarding the treatment of senile cataract. Rev Saúde Pública. 2002; 36(3):343-9.

3 Newton Kara Júnior, Edméa Rita Temporini, Newton Kara José. Cataract surgery: expectations of patients assisted during a community Project in São Paulo, State of São Paulo, Brazil. Rev Hosp Clin Fac Med Sao Paulo. 2001;56(6):163-8.

4 Newton Kara Júnior, Marcony Rodrigues Santhiago, Tais Renata Ribeiro Parede, Rodrigo França Espindola, Maysa Godoy Gomes Mazurek, Renato Germano, Newton Kara Jose. Influência da correção cirúrgica da catarata na percepção laborativa. Arq. Bras. Oftalmol. 2010;73(6):491-3.
5 Christakis PG, Braga-Mele RM. Intraoperative performance and postoperative outcome comparison of longitudinal, torsional, and transversal phacoemulsification machines. J Cataract Refract Surg. 2012; 38(2):234-41.

6 Ana Catarina Delgado de Souza, Alexandre Ventura, Catarina Ventura, João Eudes Tavares, Carlos Teixeira Brandt. One year learning curve in 160 facoemulsifications performed by a third year resident. Rev Bras Oftalmol. 2005; 64(3):156-61.

7 Chan FM, Mathur R, Ku JJ, Chen C, Chan SP, Yong VS, et al. Shortterm outcomes in eyes with posterior capsule rupture during cataract surgery. J Cataract Refract Surg. 2003; 29(3):537-41.

8 Lundström M, Behndig A, Kugelberg M, Montan P, Stenevi $\mathrm{U}$, Thorburn W. Decreasing rate of capsule complications in cataract surgery: eight-year study of incidence, risk factors, and data validity by the Swedish National Cataract Register. J Cataract Refract Surg. 2011; 37(10):1762-7.

9 Blomquist PH, Morales ME, Tong L, Ahn C. Risk factors for vitreous complications in resident-performed phacoemulsification surgery. J Cataract Refract Surg. 2012; 38(2):208-14.

10 Blomquist PH, Rugwani RM. Visual outcomes after vitreous loss during cataract surgery performed by residents. J Cataract Refract Surg. 2002; 28(5):847-52

11 Jackson Barreto Junior, Helio Primiano Junior, Rodrigo França de Espíndola, Renato Antunes Schiave Germano, Newton KaraJunior. Cirurgia de catarata realizada por residentes: avaliação dos riscos. Rev Bras Oftalmol. 2010; 69(5):301-5

12 Lundström M, Barry P, Henry Y, Rosen P, Stenevi U. Visual outcome of cataract surgery: study from the European Registry of Quality Outcomes for Cataract and Refractive Surgery. J Cataract Refract Surg. 2013; 39(5):673-9.

13 Newton Kara Junior. A situação do ensino da facoemulsificação no Brasil. Rev Bras Oftalmol. 2011;70(5):275-77.

\section{Corresponding author:}

Patricia Mencaroni Kange

Rua Tamandaré, 693 - 9th floor - Aclimação - São Paulo - SP

Zip Code 01525-001

E-mail: paty_mk@yahoo.com.br 